\title{
Endomannosidase undergoes phosphorylation in the Golgi apparatus
}

\author{
Tania Torossi, Bruno Guhl, Jürgen Roth, and Martin Ziak \\ Division of Cell and Molecular Pathology, Department of Pathology, \\ University of Zurich, CH-8091 Zurich, Switzerland \\ Received on February 22, 2009; revised on September 5, 2009; accepted on \\ September 7, 2009
}

Glucose residues from $N$-linked oligosaccharides are removed by glucosidases I and II in the endoplasmic reticulum (ER) or by the alternate endomannosidase pathway in the Golgi apparatus. Our morphological analysis demonstrates that recombinant rat endomannosidase exhibited a cis- and medial-Golgi localization alike the endogenous enzyme and its ER to Golgi transport is COP II mediated. Recombinant endomannosidase undergoes a posttranslational modification, which is not related to $N$-or $O$-glycosylation. A shift in molecular mass of recombinant endomannosidase was observed upon phosphatase digestion but not for ER-retained CHO cell endomannosidase. Furthermore, immunoprecipitation of ${ }^{35} \mathrm{~S}$ - and ${ }^{33} \mathrm{P}$-labeled endomannosidase expressed in CHO-K1 cells suggests that recombinant endomannosidase undergoes phosphorylation. Substitution of the single cytoplasmic threonine residue of rat endomannosidase by either an alanine or valine residue resulted in the same posttranslational modification alike the wild-type enzyme. The subcellular localization and the in vivo activity of the mutant endomannosidase were not affected. Thus, endomannosidase phosphorylation is occurring in luminal sequences. Modification was prevented when endomannosidase was synthesized using reticulocyte lysates in the presence of canine microsomes. Treatment of cells with brefeldin A blocked the posttranslational modification of endomannosidase, suggesting that phosphorylation is occurring in the Golgi apparatus, the residence of endomannosidase.

Keywords: endomannosidase/glucosidase II/Golgi apparatus/ $\mathrm{N}$-glycosylation/phosphorylation

\section{Introduction}

Glucose residues from asparagine-linked $\mathrm{Glc}_{3} \mathrm{Man}_{9} \mathrm{GlcNAc}_{2}$ oligosaccharides are removed by trimming reactions of glucosidases, which are localized in the endoplasmic reticulum (ER). Their action is important for the biosynthesis of $N$-linked oligosaccharides as well as for the quality control of glycoprotein folding (Parodi 2000; Roth et al. 2002; Helenius and Aebi 2004). Furthermore, the same oligosaccharide is used as a

\footnotetext{
${ }^{1}$ To whom correspondence should be addressed: Tel: +41-1-255-52-36; Fax: +41-1-255-44-07; e-mail: ziak@ access.uzh.ch
}

substrate by endo- $\alpha$-mannosidase, which provides an alternate glucosidase-independent pathway of glucose trimming in the Golgi apparatus (Lubas and Spiro 1987; Spiro et al. 1997; Spiro 2000; Zuber et al. 2000; Roth et al. 2003).

Endomannosidase cleaves the $\alpha 1,2$ linkage between the glucose-substituted mannose and the remainder mannose branch of $\mathrm{N}$-glycans. Beside tri-glucosylated oligosaccharides, di- and mono-glucosylated oligosaccharides are also processed by the enzyme, even with truncated mannose chains, which are poor substrates for glucosidase II (Lubas and Spiro 1987, 1988; Moore and Spiro 1992; Spiro et al. 1997). This unique endoglycosidase carries out a substantial amount of de-glucosylation in vivo as demonstrated by the processing of glycoproteins in HepG2 cells (Weng and Spiro 1996). In glucosidase II-deficient Phar2.7 cells (Reitman et al. 1982) or in glucosidase I-deficient CHO Lec23 cells (Ray et al. 1991; Hong et al. 2004), the processing activity of endomannosidase is essential for the maturation of oligosaccharides to hybrid and complex types. Remarkably, endomannosidase acts on both correctly folded and misfolded proteins. Thus, it provides a back-up mechanism for protein $\mathrm{N}$-glycosylation in the Golgi apparatus (Torossi et al. 2006).

Endomannosidase activity is detectable in vertebrate tissues and in a range of animal and human cell lines (Dairaku and Spiro 1997; Spiro et al. 1997; Dong et al. 2000; Zuber et al. 2000). Cloning of endomannosidase from various species (Spiro et al. 1997; Hamilton et al. 2005; Torossi et al. 2007) revealed a high interspecies amino acid sequence identity (Torossi et al. 2007). Recently, we showed that endomannosidase is an integral type II membrane protein (Stehli et al. 2008). Moreover, the first 25 $\mathrm{N}$-terminal amino acids, comprising the cytoplasmic tail and the transmembrane domain are sufficient for Golgi localization of the enzyme (Stehli et al. 2008). In contrast, glucosidase II is ER-retained by the $\beta$-subunit carrying the C-terminal KDEL retrieval sequence (Trombetta et al. 1996; Arendt and Ostergaard 1997; D'Alessio et al. 1999). Hence, distinct mechanisms ensure that the glucose-trimming enzymes are located in different compartments (Zuber et al. 2000; Roth 2002) and fulfill specific functions.

Glycoproteins bearing monoglucosylated oligosaccharides will be bound by the chaperone-like lectins calnexin or calreticulin in the ER and released after deglucosylation by glucosidase II (Roth et al. 2008). On the other hand, by the action of Golgilocalized endomannosidase, the $\mathrm{Man}_{8-5}$ GlcNAc isomer $\mathrm{A}$ is generated which is no more a substrate for re-glucosylation by UDP-glucose:glycoprotein glucosyltransferase (Parodi 2000). As a consequence, the enzymatic activity of endomannosidase in the ER must be inhibited allowing a quality control of glycoprotein folding and assembly by the calnexin/calreticulin cycle (Helenius and Aebi 2004).

In the present study, we report the biosynthesis of endomannosidase as well as its ER to Golgi transport. Furthermore, we 


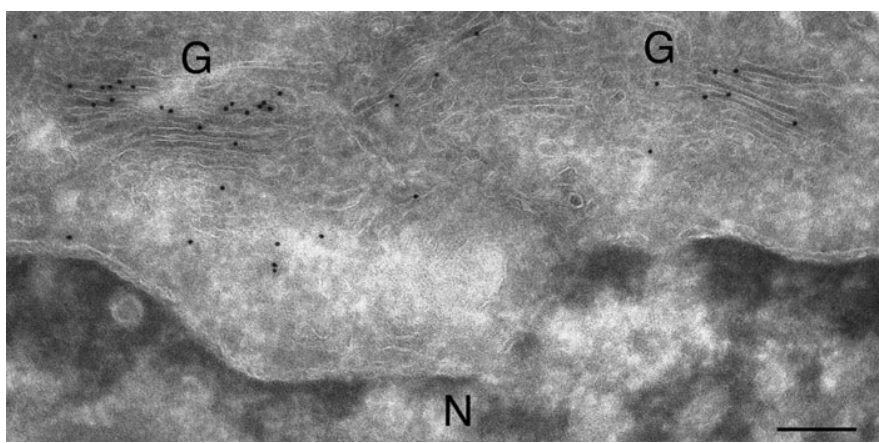

Fig. 1. Recombinant rat endomannosidase is localized in the Golgi apparatus. Immunogold labeling for myc-tagged rEndo in the cis- and medial-Golgi cisternae and in transport vesicles. N nucleus; G Golgi apparatus. Bar $100 \mathrm{~nm}$.

demonstrate that endomannosidase undergoes phosphorylation in the Golgi apparatus.

\section{Results}

ER to Golgi transport of endomannosidase is COP II mediated Endomannosidase represents a glucose trimming endoglycosidase in the Golgi apparatus and in pre-Golgi intermediates (Zuber et al. 2000). Double immunofluoresence showed that recombinant myc-tagged rat endomannosidase (rEndo) expressed in CHO-K1 cells and in clone 9 hepatocytes, respectively, retained its inherent Golgi localization (Torossi et al. 2007; Stehli et al. 2008). By immunoelectron microscopy, the recombinant enzyme was found in the cis- and medial-Golgi apparatus and additionally in vesicles (Figure 1). Thus, the recombinant rEndo exhibited a similar subcellular distribution as the endogenous enzyme (Zuber et al. 2000). In general, transport between ER and Golgi apparatus is mediated by COPII-coated vesicles (Hughes and Stephens 2008). We investigated whether recombinant rEndo, expressed in CHO-K1 cells, is a cargo in COP II transport vesicles. Indeed, immunoprecipitated sec23 protein complexes contained recombinant rat endomannosidase (rEndo) or rEndo lacking the positively charged amino acids in the cytoplasmic tail (rEndoR ${ }_{5-7} \mathrm{I}$ ) (Stehli et al. 2008) (Figure 2). Hence, the transport of myc-tagged rEndo from ER to Golgi appears to occur in COP II-vesicles.

\section{Rat endomannosidase is a nonglycosylated protein}

To study the biosynthesis of the enzyme, we expressed the myc-tagged rEndo in CHO-K1 cells as well as in clone 9 rat hepatocytes. Immunoprecipitated endomannosidase from metabolically labeled cells showed a time-dependent increase in molecular mass. Initially the enzyme was synthesized as a $53 \mathrm{kDa}$ protein (Figure 3). After a chase period of $30 \mathrm{~min}$, three bands with higher molecular mass were observed indicating that rEndo undergoes a posttranslational modification. After $2 \mathrm{~h}$ chase, the conversion was completed yielding mature rat endomannosidase $\left(\mathrm{rEndo}_{\mathrm{m}}\right)$ with molecular mass of 58 and $60 \mathrm{kDa}$. Both bands were detectable even after chase periods of up to $24 \mathrm{~h}$ (data not shown). When we expressed the recombinant enzyme in clone 9 hepatocytes the same increase in molecular mass was observed. Previously, no consensus Asn-linked glycosylation

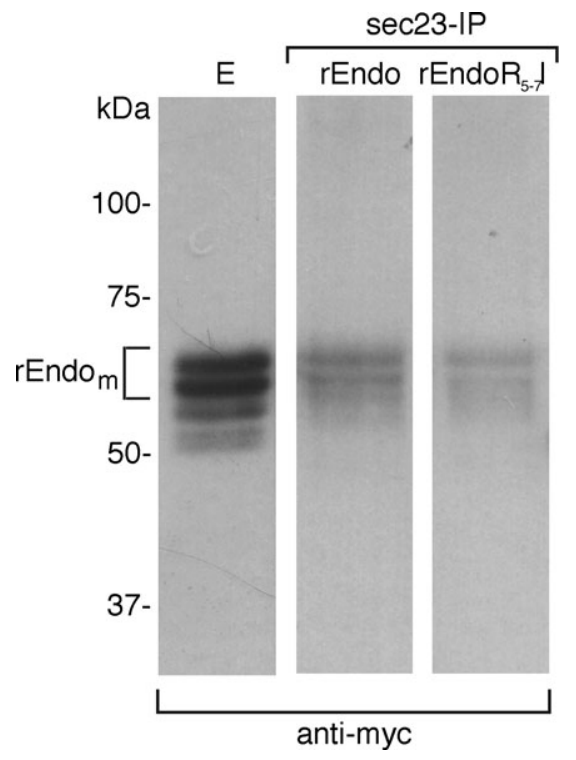

Fig. 2. ER to Golgi transport of endomannosidase is COP II-mediated. Immunoblot analysis of extracts from $\mathrm{CHO}-\mathrm{K} 1$ cells expressing myc-tagged rEndo (E). Immunoprecipitated sec23-protein vesicles from CHO-K1 cells contain myc-tagged rat endomannosidase (rEndo) or myc-tagged rat endomannosidase $\mathrm{R}_{5-7} \mathrm{I}$ (rEndo $\left.\mathrm{R}_{5-7} \mathrm{I}\right)$ ). $\mathrm{EEndo}_{\mathrm{m}}$; mature forms of rat endomannosidase.

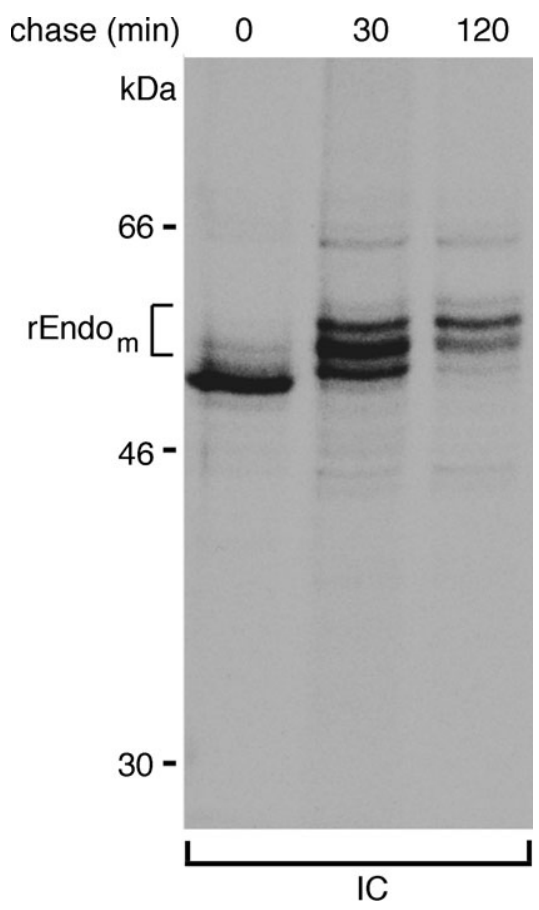

Fig. 3. Rat endomannosidase undergoes a posttranslational modification. CHO-K1 cells expressing myc-tagged rEndo were pulsed for $20 \mathrm{~min}$ and chased for the time period indicated. Cell lysates (IC) were immunoprecipitated with anti-myc antibodies and analyzed by $8 \%$ SDS-PAGE/fluorography. The molecular mass of recombinant rEndo increased time dependently from $53 \mathrm{kDa}(0 \mathrm{~min})$ to $58 \mathrm{kDa}$ and $60 \mathrm{kDa}$ (120 min), respectively. The latter two represent the mature forms of rat endomannosidase, $\mathrm{rEndo}_{\mathrm{m}}$. 


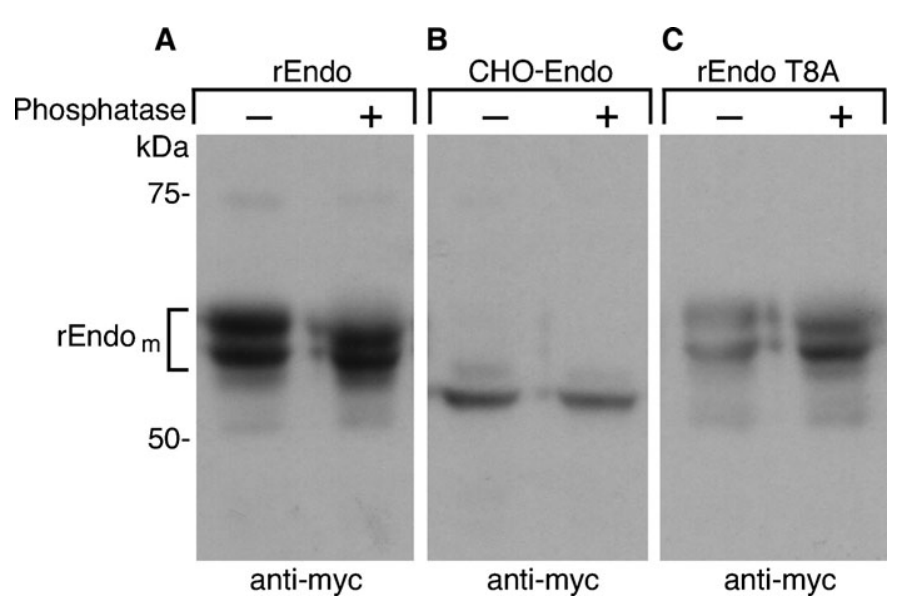

Fig. 4. Rat endomannosidase is phosphorylated. Immunoblot analysis of CHO-K1 cell extracts expressing Golgi-localized myc-tagged rat endomannosidase (A), ER-localized myc-tagged $\mathrm{CHO}$ cell endomannosidase (B), or Golgi-localized myc-tagged Thr8Ala-rat endomannosidase $(\mathbf{C})$ in the absence $(-)$ or presence $(+)$ of phosphatase. Phosphatase treatment results in a shift of Golgi-localized rat endomannosidases whereas ER-localized CHO cell endomannosidase is not influenced. $\mathrm{rEndo}_{\mathrm{m}}$, mature forms of rat endomannosidase.

sites were identified in the cloned enzyme (Hamilton et al. 2005; Torossi et al. 2007). Not unexpected, Endo H or PNGase F treatment of mature recombinant rEndo from CHO-K1 cells or from clone 9 hepatocytes did not reduce its molecular mass (data not shown). No evidence for the presence of serine/threonine-linked oligosaccharide side chains on rEndo was obtained by lectin blot analysis using the Vicia villosa isolectin $\mathrm{B}_{4}$, the Sophora japonica, the Dolichos biflorus, the Wistaria floribunda, and the Amaranthus caudatus lectins (Goldstein and Poretz 1986). Furthermore, treatment of CHO-K1 cells expressing rEndo with the $O$-glycosylation inhibitor benzyl-GalNac or benzyl-GalGalNac (Ramachandran and Peterkofsky 1997) did not result in a shift in the molecular mass of recombinant rEndo suggesting that no elongation of $O$-glycosyl chains occurred (data not shown). Thus, the posttranslational modification of rEndo is not related to $\mathrm{N}$ - or $O$-linked glycosylation.

\section{Rat endomannosidase is phosphorylated}

To further analyze the nature of the posttranslational modification, recombinant rEndo and $\mathrm{CHO}$ endomannosidase (Torossi et al. 2007) were subjected to phosphatase treatment. A shift in molecular mass was observed for rEndo (Figure 4A and C) but not for $\mathrm{CHO}$ endomannosidase (Figure 4B) upon such a treatment. Thus, we concluded that rEndo is phosphorylated either on a single cytoplasmic threonine or on luminal serine, threonine, or tyrosine residues (Torossi et al. 2007). To substantiate this finding, we expressed both rEndo and CHO endomannosidase in CHO-K1 cells and labeled these cells for $5 \mathrm{~h}$ with ${ }^{33} \mathrm{P}$ (Figure 5). Immunoprecipitated rEndo was labeled with ${ }^{33} \mathrm{P}$, indicating that it is modified by phosphate residues (Figure 5A). In contrast, no ${ }^{33} \mathrm{P}$ incorporation was observed for the ER-retained CHO endomannosidase (Figure 5B). Furthermore, no increase in molecular mass was observed when either rEndo or rEndo lacking its transmembrane domain ( $\triangle \mathrm{TMD}$-ratEndo) (Stehli et al. 2008) was synthesized with an in vitro transcription/translation system in the presence of canine microsomes
A
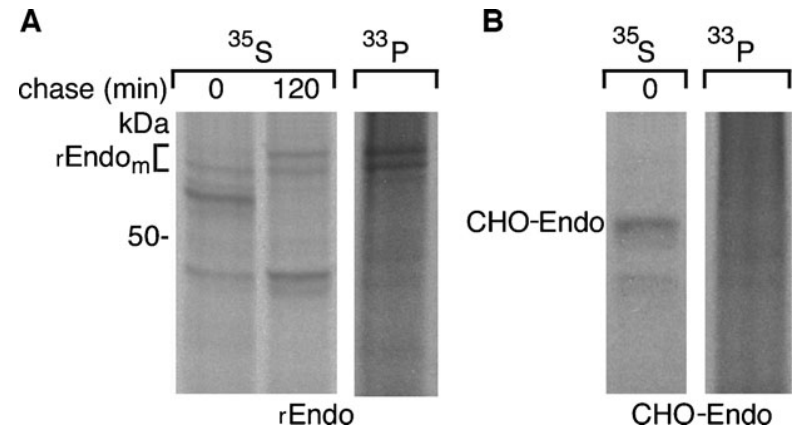

Fig. 5. Only Golgi-localized rat endomannosidase became phosphorylated. CHO-K1 cells stably expressing either Golgi-localized myc-tagged rEndo (A) or ER-localized CHO cell endomannosidase (B) were labeled either with $100 \mu \mathrm{Ci} / \mathrm{mL}^{35} \mathrm{~S}$ or with $700 \mu \mathrm{Ci} / \mathrm{mL}^{33} \mathrm{P}$ (see Material and methods). Myc-tagged endomannosidases were immunoprecipitated from cell lysates and analyzed by $8 \%$ SDS-PAGE/fluorography.

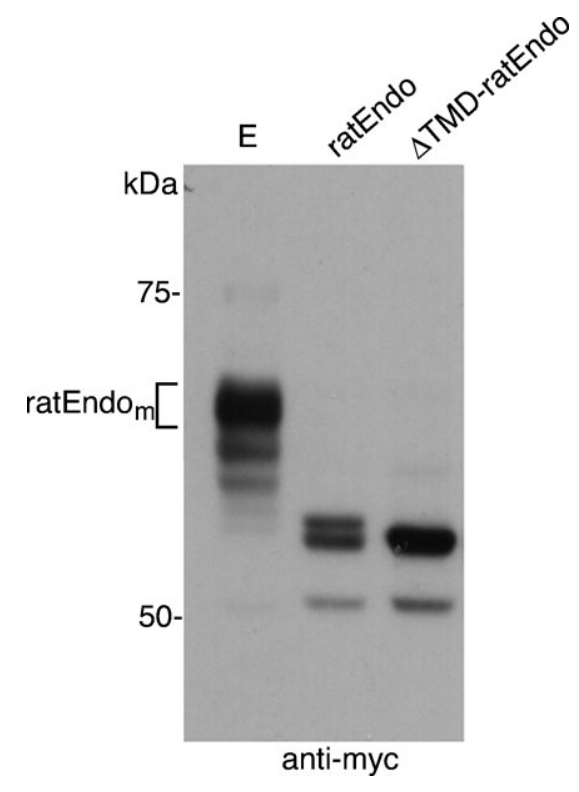

Fig. 6. Posttranslational modification of rat endomannosidase occurs during passage along the secretory pathway. Immunoblot analysis of extracts from $\mathrm{CHO}$ cells expressing my-tagged rat endomannosidase (E) of rat endomannosidase (ratEndo) and of rat endomannosidase lacking its transmembrane domain ( $\triangle$ TMD-ratEndo), both synthesized in vitro using a reticulocyte lysate system in the presence of canine microsomes. ratEndo $\mathrm{m}_{\mathrm{m}}$, mature form of rat endomannosidase.

(Figure 6). However, in vitro synthesis of human $\alpha 1$-antitrypsin yielded EndoH-sensitive species indicating the occurrence of posttranslational modification (data not shown). Similarly, the two bands observed during synthesis of rEndo (Figure 6) might be due to the cleavage of the signal peptide. Thus, we concluded that the posttranslational modification of rat endomannosidase occurs during its passage along the secretory pathway. In order to substantiate that phosphorylation or rEndo might occur in the Golgi apparatus, we used the drug brefeldin A which causes the flow back of cis-, medial-, and trans-cisternae of the Golgi into the ER while leaving the trans-Golgi network intact (Lippincott-Schwartz et al. 1989). Treatment of CHO-K1 cells 


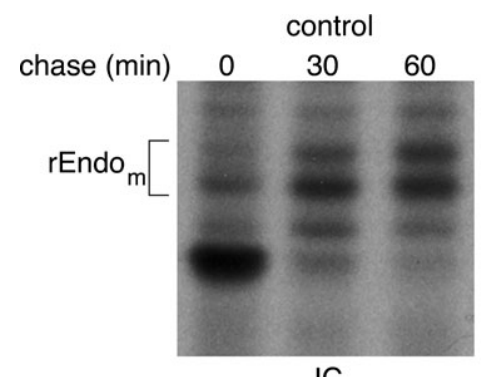

IC

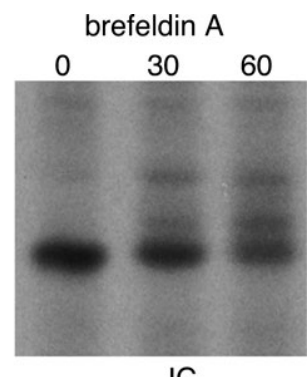

IC
Fig. 7. Brefeldin A prevents the maturation of endomannosidase. CHO-K1 cells expressing Golgi-localized myc-tagged rEndo were preincubated or not for $1 \mathrm{~h}$ with brefeldin A $(2.5 \mu \mathrm{g} / \mathrm{mL})$, pulsed for $20 \mathrm{~min}$ with ${ }^{35} \mathrm{~S}$-methionine, and chased for the time periods indicated. Cell lysates (IC) were immunoprecipitated with anti-myc antibodies and analyzed by $8 \%$ SDS-PAGE/fluorography. Brefeldin A blocked the formation of the $58 \mathrm{kDa}$ and $60 \mathrm{kDa}$ mature form of endomannosidase $\left(\mathrm{rEndo}_{\mathrm{m}}\right)$.

with BFA abolished the shift in molecular mass of rEndo (Figure 7). Hence, phosphorylation occurred in the Golgi apparatus, the residence of endomannosidase.

\section{Rat endomannosidase is phosphorylated in its luminal domain}

By site-directed mutagenesis we replaced the single threonine at position 8 in the cytoplasmic tail rEndo by either a valine or alanine residue and expressed the mutant proteins in CHO-K1 cells. Western blot analysis of CHO-K1 cell extracts showed that both rEndo T8A and T8V undergo the same posttranslational modification alike the wild-type enzyme (Figure 4C). Phosphatase treatment of rEndo T8A (Figure 4C) or of rEndo T8V (data not shown) resulted in a shift in molecular mass alike the wild-type enzyme (Figure 4A) suggesting that the single threonine residue in the cytoplasmic tail of rEndo might not be phosphorylated. Double confocal immunofluorescence showed a Golgi localization for rEndo T8A (Figure 8A-C) and for rEndo T8V (data not shown). Furthermore, both mutant rat endomannosidases exhibited fully enzymatic activity (Figure 8D) in processing the $N$-linked oligosaccharides of $\alpha 1$-antitrypsin (Torossi et al. 2007).

\section{Discussion}

In the present study, we showed that recombinant rat endomannosidase (rEndo) exhibited an inherent Golgi localization\ alike the endogenous enzyme (Zuber et al. 2000; Stehli et al. 2008; present study). Thus, the recombinant enzyme seems to be properly folded in order to exit the endoplasmic reticulum (ER) (Parodi 2000; Roth et al. 2002; Helenius and Aebi 2004) whereas recombinant $\mathrm{CHO}$ cell endomannosidase was ER retained. Recently, we established the molecular defect in $\mathrm{CHO}$ cell endomannosidase causing its mislocalization and reduced in vivo activity namely a single Trp188/Cys substitution (Torossi et al. 2007). The export of proteins from the ER is a highly selective process involving COP II transport vesicles (Hughes and Stephens 2008). Indeed, our present biochemical data demonstrate that recombinant rEndo, a type II membrane protein, is a cargo of the COP II complex. Therefore, we conclude that ER to Golgi transport of endomannosidase is COP II-mediated. Several amino acid motifs such as di-acidic, di-hydrophobic, or di-aromatic sequences were identified to serve as ER export signals. Recently, another type of ER export signal has been described consisting of di-basic amino acids, located proximal to the transmembrane region of Golgi-resident glycosyltransferase. The interaction of the COP II component Sar1p with the di-basic motif seems to be a critical selection of type II membrane proteins as cargo of COP II transport vesicles along the secretory pathway (Giraudo and Maccioni 2003). Cloning of endomannosidase from various species (Hamilton et al. 2005; Torossi et al. 2007) showed that they share as a common feature a cluster of arginine residues in their cytoplasmic tail suggesting that these positively charged amino acids might act as an ER export signal. However, substitution of these amino acid residues by neutral amino acids did not prevent Golgi localization (Stehli et al. 2008; present study). Thus, not only the positively charged amino acids but also structural information of the amino acid side chain influences the ER to Golgi transport competence.

The transport of proteins from the ER to the Golgi apparatus is often accompanied by various posttranslational modifications such as glycosylation, phosphorylation, or sulfation. Indeed, our biochemical analysis demonstrated that recombinant rEndo undergoes a posttranslational modification, which was not related to $N$ - or $O$-glycosylation. Phosphatase treatment and in vitro phosphorylation experiments showed that the enzyme is phosphorylated on luminal Ser, Thr, or Tyr residues. However, alkaline phosphatase treatment did not completely abolish the increase in molecular mass. Thus, we conclude that rEndo undergoes phosphorylation beside additional modifications, which remain to be identified. It is well known that various secretory proteins with different biological functions become phosphorylated along the secretory pathway (Wang and Williams 1982; Oetting et al. 1986; Gaut and Hendershot 1993; Swift 1996). Amongst Golgi-localized glycosyltransferases, isoforms of $\alpha 2,6$-sialyltransferase (ST6Gal-I) are phosphorylated on Ser and $\mathrm{Thr}$ residues in their luminal sequences in various cell types (Ma et al. 1999), whereas Ser residues within the cytosolic tail of $\beta 1$,4-galactosyltransferase 1 (GalT) are phosphorylated (Strous et al. 1987).

The fact that ER retained $\mathrm{CHO}$ cell endomannosidase (Torossi et al. 2007) failed to undergo phosphorylation together with data obtained from our in vitro transcription/translation system suggested that rat endomannosidase phosphorylation occurred in a past ER compartment. Using the drug brefeldin A (Fujiwara et al. 1988; Lippincott-Schwartz et al. 1989), we established the Golgi apparatus as the site of phosphorylation of rEndo. However, we cannot exclude the possibility that rEndo undergoes this posttranslational modification in COP II vesicles. Actually, kinase activities were not only identified in the lumen of the ER (Hendershot et al. 1988), but also in the Golgi apparatus (West and Clegg 1984; Rosa et al. 1992). Moreover, Hirschberg and colleagues (Capasso et al. 1989) identified a functional ATP transporter in the Golgi membrane. Recently, a protein kinase, which phosphorylates serine or threonine residue within atypical cadherin, was identified in the Golgi apparatus (Ishikawa et al. 2008). Thus, our work on rEndo provides additional evidence that phosphorylation of secretory proteins does not occur exclusively in the ER but also in the Golgi apparatus.

Many functions have been attributed to the phoshorylation of proteins. Cell surface localization and function of GalT was influenced by this posttranslational modification (Hathaway et al. 2003). For ST6Gal-I, it was hypothesized that phosphorylation 

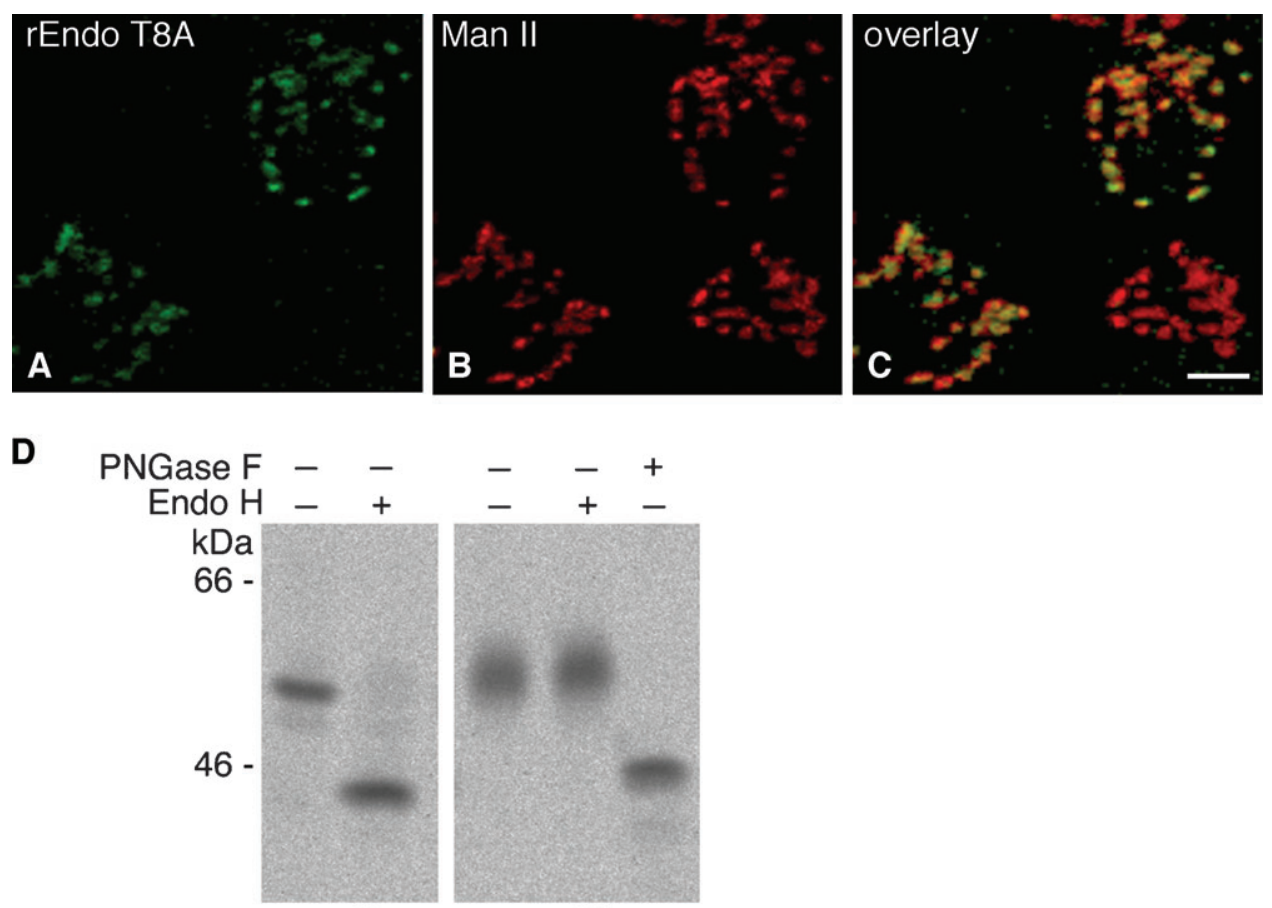

IC

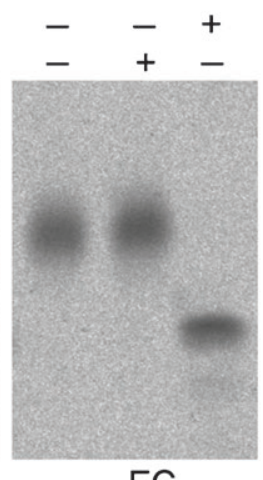

EC

Fig. 8. Engineered rat Endo T8A expressed in CHO-K1 cells exhibited Golgi localization. Confocal double immunofluorescence for myc-tagged rEndo T8A (A) and Golgi mannosidase II (B) showed codistribution $(\mathbf{C})$. Bar, $10 \mu \mathrm{m}$. Processing of immunoprecipitated $\alpha 1$-antitrypsin by rEndo T8A from CHO Lec23 cells was analyzed (D). The oligosaccharides of intracellular $\alpha 1$-antitrypsin (IC) were Endo H sensitive, whereas oligosaccharides of secreted $\alpha 1$-antitrypsin (EC) were fully processed as indicated by Endo $\mathrm{H}$ resistance and PNGase F-sensitivity.

controls the trafficking to and/or cleavage within the late Golgi apparatus or a post-Golgi compartment (Ma et al. 1999). Furthermore, phosphorylation of a single Ser residue in aquaporin 2 by protein kinase A serves as a key signal for its insertion into the plasma membrane in renal cells (Procino et al. 2003). Control of enzymatic activity or regulation of a protein halflife, as observed for many protein kinases, might be another function of phosphorylation (Hunter 2007). The functional importance of phosphorylation on endomannosidase remains to be investigated in further studies. However, we speculate that the enzymatic activity of Golgi endomannosidase might be controlled by phosphorylation. Finally, one also has to consider that a non-functional phosphorylation can occur (Lienhard 2008).

\section{Material and methods}

\section{Antibodies and reagents}

The mouse monoclonal anti-myc antibody was from Upstate (Milton Keynes, UK), the polyclonal anti-myc-, the polyclonal anti-sec23, and the polyclonal anti-COP II antibody from Abcam (Cambridge, UK). Horseradish peroxidase-conjugated goat anti-rabbit IgG and goat anti-mouse IgG were purchased from Jackson ImmunoResearch Laboratories, Inc. (West Grove, PA). Protease inhibitor tablets, Endo H, PNGase F, and alkaline phosphatase from calf intestine were purchased from Roche Diagnostics (Rotkreuz, Switzerland); TNT coupled reticulocyte lysate systems and canine microsomes from Promega (Wallisellen, Switzerland); pcDNA6/myc-His, competent $E$. coli DH5 $\alpha$ cells, lipofectamine 2000, cell culture media and fetal bovine serum from Invitrogen (Basel, Switzerland). ${ }^{35}$ S-labeled methionine was purchased from Anawa Trading SA (Wangen, Switzerland) and ${ }^{33} \mathrm{P}$ from GE healthcare (Otelfingen, Switzerland). Protein A magnetic beads were from Dynal (Hamburg, Germany), biotinylated- or digoxigenin-conjugated lectins, digitonin and all other chemicals of analytical grade from Sigma (Buchs, Switzerland).

\section{Cell lines and transfection}

CHO-K1 cells and clone 9 rat hepatocytes were obtained from American Type Culture Collection (Manassas, VA) and grown in Ham's F12 medium containing $10 \%$ fetal bovine serum at $37^{\circ} \mathrm{C}$ in a $5 \% \mathrm{CO}_{2}$ incubator. The $\mathrm{CHO}$ Lec 23 cells (Ray et al. 1991; Hong et al. 2004) were kindly provided by Dr. Pamela Stanley (New York, NY) and cultured in Eagle's minimal essential medium (alpha modification) containing 10\% fetal bovine serum (FBS). Stable transfections were performed as described previously (Torossi et al. 2007; Stehli et al. 2008).

\section{Site-directed mutagenesis in rat endomannosidase}

Mutant rEndo were generated by a PCR-based site-directed mutagenesis strategy as described (Stehli et al. 2008).

\section{Metabolic labeling, immunoprecipitation, and SDS-PAGE}

CHO-K1 cells or clone 9 hepatocytes stably expressing myctagged rEndo (Torossi et al. 2007; Stehli et al. 2008) were incubated in methionine-free DMEM for $30 \mathrm{~min}$ at $37^{\circ} \mathrm{C}$ in a $5 \% \mathrm{CO}_{2}$ incubator. Afterward, cells were labeled in medium containing $100 \mu \mathrm{Ci} / \mathrm{mL}^{35} \mathrm{~S}$-methionine for $20 \mathrm{~min}$ and chased 
with medium containing cold methionine $(1 \mathrm{mM})$ for the indicated time points. Cells treated with brefeldin A (BFA) were preincubated in medium containing $2.5 \mu \mathrm{g} / \mathrm{mL}$ BFA for $1 \mathrm{~h}$. The same concentration of BFA was maintained throughout the methionine-depletion, labeling, and chase periods. Cells were washed with ice-cold phosphate-buffered saline $\mathrm{pH} 7.4$ (PBS), mechanically removed with a rubber policeman and resuspended in PBS containing protease inhibitors. Proteins were extracted with Triton X-100 $\left(1 \%, 1 \mathrm{~h}\right.$ at $\left.4^{\circ} \mathrm{C}\right)$ and cell debris removed by centrifugation. The cell extracts and the corresponding culture mediums were added to protein A magnetic beads conjugated with a rabbit anti-myc antibody and incubated for $16 \mathrm{~h}$ at $4{ }^{\circ} \mathrm{C}$. Immunoprecipitates were washed with PBS containing $0.1 \%$ Triton X-100 and analyzed by $8 \%$ SDSpolyacrylamide gel electrophoresis (SDS-PAGE).

\section{Combined immunoprecipitations/immunoblot analysis}

Immunoprecipitations of myc-tagged rEndo were performed as described above. For COPII immunoprecipitations, anti$\sec 23$ antibodies, crosslinked to magnetic beads, were added to digitonin-lysed cells. Immunoprecipitates and $\mathrm{CHO}$ cell extracts were analyzed by $8 \%$ SDS-PAGE and transferred onto nitrocellulose membranes using a semidry blotting apparatus (Towbin et al. 1979). The nitrocellulose membranes were blocked in PBS containing 1\% BSA for $1 \mathrm{~h}$ at ambient temperature and incubated with a mouse anti-myc antibody, overnight at $4{ }^{\circ} \mathrm{C}$ followed by the incubation with the corresponding horseradishconjugated secondary antibody for enhanced chemiluminescence detection.

\section{Phosphatase digestion, glycosidase treatment, and lectin blotting}

For phosphatase digestion, $\mathrm{CHO}-\mathrm{K} 1$ cell extracts were digested with $2 \mathrm{U}$ alkaline phosphatase for $16 \mathrm{~h}$ at $37^{\circ} \mathrm{C}$. The samples were analyzed by SDS-PAGE/immunoblotting as described above. Immunoprecipitated myc-tagged rEndo was subjected to Endo $\mathrm{H}$ and PNGase $\mathrm{F}$ treatment as described previously (Torossi et al. 2006). For lectin blotting, the nitrocellulose membranes were either incubated with digoxigenin-conjugated or biotinylated lectins according to the manufacturer's instructions. Lectin binding was detected by using alkaline phosphataseconjugated polyclonal sheep anti-digoxigenin Fab' fragments or alkaline phosphatase-conjugated streptavidin. Enzyme activity was revealed by using the nitroblue tetrazolium/X-phosphate substrate system. As control for lectin blotting, nitrocellulose stripes containing immobilized rat megalin was used (Ziak et al. 1999).

\section{In vivo phosphorylation of rat endomannosidase}

For labeling of proteins with ${ }^{33} \mathrm{P}, \mathrm{CHO}-\mathrm{K} 1$ cells expressing myctagged rEndo or CHO endomannosidase (Torossi et al. 2007; Stehli et al. 2008) were incubated in DMEM medium without sodium phosphate for $30 \mathrm{~min}$ at $37^{\circ} \mathrm{C}$ in a $5 \% \mathrm{CO}_{2}$ incubator. Cells were labeled in medium containing $700 \mu \mathrm{Ci} / \mathrm{mL}$ of ${ }^{33} \mathrm{P}$ for $5 \mathrm{~h}$ at $37^{\circ} \mathrm{C}$. Lysis of the cells and analysis of the immunoprecipitates were performed as described above. Radioactivity was visualized by autoradiography or by using a phosphorimager (FUJI Film Corp., Japan).

\section{In vitro transcription and translation}

Coupled, nonradioactive in vitro transcription and translation, in the presence or absence of canine microsomes, was performed with $1 \mu \mathrm{g}$ of Fsp I-linearized pcDNA6/rat- or CHO endomannosidase (Torossi et al. 2007) as a template in a total reaction volume of $25 \mu \mathrm{L}$, according to the manufacturer's instructions. As a control, $1 \mu \mathrm{g}$ of Sca I-linearized pcDNA3/ $\alpha 1$-antitrypsin (Torossi et al. 2006) was used. At the end, $5 \mu \mathrm{L}$ of reaction mixtures was analyzed by SDS-PAGE/immunoblotting blotting as described above.

\section{Confocal immunofluorescence microscopy and in vivo endomannosidase assay}

Transfected CHO-K1 cells grown as a monolayer on glass cover slips were formaldehyde fixed and saponin permeabilized. Double immunolabeling incubations were performed as described (Stehli et al. 2008). Endomannosidase activity was determined on the basis of the processing of the oligosaccharides of human $\alpha 1$-antitrypsin (Stehli et al. 2008).

\section{Immunoelectron microscopy}

CHO-K1 cells were fixed in $3 \%$ paraformaldehyde in PBS, embedded in low-melting agarose, and infiltrated with a sucrosepolyvinol pyrrolidone mixture. Frozen ultrathin cryosections were prepared according to Tokuyasu $(1978,1980)$, incubated with a mouse anti-myc antibody followed by a $8 \mathrm{~nm}$ gold-labeled secondary antibody according to standard protocols (Roth et al. 1978).

\section{Funding}

The Canton of Zurich; the EMDO Stiftung (Zurich); the Theodor and Ida Herzog-Egli Stiftung (Zurich); and the Swiss National Science Foundation.

\section{Acknowledgements}

We thank Dr. R. G. Spiro (Harvard Medical School, Boston, MA) for providing endomannosidase antibody and Prof. Dr. H. Moch (Department of Pathology, University of Zurich) for taking over the printing costs of this article.

\section{Conflict of interest statement}

None declared.

\section{References}

Arendt CW, Ostergaard HL. 1997. Identification of the CD45-associated 116$\mathrm{kDa}$ and $80-\mathrm{kDa}$ proteins as the $\alpha$ - and $\beta$-subunits of $\alpha$-glucosidase II. $J$ Biol Chem. 272:13117-13125.

Capasso JM, Keenan TW, Abeijon C, Hirschberg CB. 1989. Mechanism of phosphorylation in the lumen of the Golgi apparatus. Translocation of adenosine 5 -triphosphate into Golgi vesicles from rat liver and mammary gland. J Biol Chem. 264:5233-5240.

D'Alessio C, Fernandez F, Trombetta ES, Parodi AJ. 1999. Genetic evidence for the heterodimeric structure of glucosidase: II. The effect of disrupting the subunit-encoding genes on glycoprotein folding. J Biol Chem. 274:25899_ 25905. 
Dairaku K, Spiro RG. 1997. Phylogenetic survey of endomannosidase indicates late evolutionary appearance of this $N$-linked oligosaccharide processing enzyme. Glycobiology. 7:579-586.

Dong Z, Zuber C, Spiro MJ, Spiro RG, Roth J. 2000. Immunohistochemical evaluation of endomannosidase distribution in rat tissues: Evidence for cell type-specific expression. Histochem Cell Biol. 114:461-467.

Fujiwara T, Oda K, Yokota S, Takatsuki A, Ikehara Y. 1988. Brefeldin A causes disassembly of the Golgi complex and accumulation of secretory proteins in the endoplasmic reticulum. J Biol Chem. 263:18545-18552.

Gaut JR, Hendershot LM. 1993. The immunoglobulin-binding protein in vitro autophosphorylation site maps to a threonine within the ATP binding cleft but is not a detectable site of in vivo phosphorylation. J Biol Chem. 268:12691-12698.

Giraudo CG, Maccioni HJ. 2003. Endoplasmic reticulum export of glycosyltransferases depends on interaction of a cytoplasmic dibasic motif with Sar1. Mol Biol Cell. 14:3753-3766.

Goldstein IJ, Poretz RD. 1986. Isolation, physicochemical characterization, and carbohydrate-binding specificity of lectins. In: Liener IE, Sharon N, Goldstein IJ, editors. The Lectins. Properties, Functions and Applications in Biology and Medicine. Orlando (FL): Academic Press. p. 35-247.

Hamilton SR, Li H, Wischnewski H, Prasad A, Kerley-Hamilton JS, Mitchell T, Walling AJ, Davidson RC, Wildt S, Gerngross TU. 2005. Intact $\alpha-1,2-$ endomannosidase is a typical type II membrane protein. Glycobiology. 15:615-624.

Hathaway HJ, Evans SC, Dubois DH, Foote CI, Elder BH, Shur BD. 2003. Mutational analysis of the cytoplasmic domain of $\beta 1$,4-galactosyltransferase: I. Influence of phosphorylation on cell surface expression. J Cell Sci. 116:4319-4330.

Helenius A, Aebi M. 2004. Roles of $N$-linked glycans in the endoplasmic reticulum. Anпu Rev Biochem. 73:1019-1049.

Hendershot LM, Ting J, Lee AS. 1988. Identity of the immunoglobulin heavychain-binding protein with the 78,000-dalton glucose-regulated protein and the role of posttranslational modifications in its binding function. Mol Cell Biol. 8:4250-4256.

Hong Y, Sundaram S, Shin DJ, Stanley P. 2004. The Lec23 Chinese hamster ovary mutant is a sensitive host for detecting mutations in $\alpha$-glucosidase I that give rise to congenital disorder of glycosylation IIb (CDG IIb). J Biol Chem. 279:49894-49901.

Hughes H, Stephens DJ. 2008. Assembly, organization, and function of the COPII coat. Histochem Cell Biol. 129:129-151.

Hunter T. 2007. The age of crosstalk: Phosphorylation, ubiquitination, and beyond. Mol Cell. 28:730-738.

Ishikawa HO, Takeuchi H, Haltiwanger RS, Irvine KD. 2008. Four-jointed is a Golgi kinase that phosphorylates a subset of cadherin domains. Science. 321:401-404.

Lienhard GE. 2008. Non-functional phosphorylations? Trends Biochem Sci. 33:351-352.

Lippincott-Schwartz J, Yuan L, Bonifacino J, Klausner R. 1989. Rapid redistribution of Golgi proteins into the ER in cells treated with Brefeldin A: Evidence for membrane cycling from Golgi to ER. Cell. 56:801-813.

Lubas WA, Spiro RG. 1987. Golgi endo- $\alpha$-D-mannosidase from rat liver, a novel $N$-linked carbohydrate unit processing enzyme. J Biol Chem. 262:37753781.

Lubas WA, Spiro RG. 1988. Evaluation of the role of rat liver Golgi endo$\alpha$-D-mannosidase in processing $N$-linked oligosaccharides. J Biol Chem. 263:3990-3998.

Ma J, Simonovic M, Qian R, Colley KJ. 1999. Sialyltransferase isoforms are phosphorylated in the cis-medial Golgi on serine and threonine residues in their luminal sequences. J Biol Chem. 274:8046-8052.

Moore SE, Spiro RG. 1992. Characterization of the endomannosidase pathway for the processing of $N$-linked oligosaccharides in glucosidase II-deficient and parent mouse lymphoma cells. J Biol Chem. 267:8443-8451.

Oetting WS, Tuazon PT, Traugh JA, Walker AM. 1986. Phosphorylation of prolactin. J Biol Chem. 261:1649-1652.

Parodi AJ. 2000. Protein glucosylation and its role in protein folding. Annu Rev Biochem. 69:69-93.

Procino G, Carmosino M, Marin O, Brunati AM, Contri A, Pinna LA, Mannucci R, Nielsen S, Kwon TH, Svelto M, et al. 2003. Ser-256 phosphorylation dynamics of Aquaporin 2 during maturation from the ER to the vesicular compartment in renal cells. FASEB J. 17:1886-1888.

Ramachandran U, Peterkofsky B. 1997. Aberrant $O$-glycosylation in the collagenous domain of pro alpha2(I) procollagen subunits synthesized by chemically transformed hamster fibroblasts. Arch Biochem Biophys. 342:29-37.
Ray MK, Yang J, Sundaram S, Stanley P. 1991. A novel glycosylation phenotype expressed by Lec23, a Chinese hamster ovary mutant deficient in a-glucosidase I. J Biol Chem. 266:22818-22825.

Reitman ML, Trowbridge IS, Kornfeld S. 1982. A lectin-resistant mouse lymphoma cell line is deficient in glucosidase II, a glycoprotein-processing enzyme. J Biol Chem. 257:10357-10363.

Rosa P, Mantovani S, Rosboch R, Huttner WB. 1992. Monensin and brefeldin A differentially affect the phosphorylation and sulfation of secretory proteins. J Biol Chem. 267:12227-12232.

Roth J. 2002. Protein N-glycosylation along the secretory pathway: Relationship to organelle topography and function, protein quality control, and cell interactions. Chem Rev. 102:285-303.

Roth J, Bendayan M, Orci L. 1978. Ultrastructural localization of intracellular antigens by the use of protein A-gold complex. J Histochem Cytochem. 26:1074-1081.

Roth J, Yam GH, Fan J, Hirano K, Gaplovska-Kysela K, Le Fourn V, Guhl B, Santimaria R, Torossi T, Ziak M, et al. 2008. Protein quality control: The who's who, the where's and therapeutic escapes. Histochem Cell Biol. 129:163-177.

Roth J, Ziak M, Zuber C. 2003. The role of glucosidase II and endomannosidase in glucose trimming of asparagine-linked oligosaccharides. Biochimie. 85:287-294.

Roth J, Zuber C, Guhl B, Fan JY, Ziak M. 2002. The importance of trimming reactions on asparagine-linked oligosaccharides for protein quality control. Histochem Cell Biol. 117:159-169.

Spiro RG. 2000. Glucose residues as key determinants in the biosynthesis and quality control of glycoproteins with $N$-linked oligosaccharides. $J$ Biol Chem. 275:35657-35660.

Spiro MJ, Bhoyroo VD, Spiro RG. 1997. Molecular cloning and expression of rat liver endo- $\alpha$-mannosidase, an $N$-linked oligosaccharide processing enzyme. J Biol Chem. 272:29356-29363.

Stehli J, Torossi T, Ziak M. 2008. Triple arginines in the cytoplasmic tail of endomannosidase are not essential for type II membrane topology and Golgi localization. Cell Mol Life Sci. 65:1609-1619.

Strous GJ, van Kerkhof P, Fallon RJ, Schwartz AL. 1987. Golgi galactosyltransferase contains serine-linked phosphate. Eur J Biochem. 169:307-311.

Swift LL. 1996. Role of the Golgi apparatus in the phosphorylation of apolipoprotein B. J Biol Chem. 271:31491-31495.

Tokuyasu K. 1978. A study of positive staining of ultrathin frozen sections. J Ultrastruct Res. 63:287-307.

Tokuyasu K. 1980. Immunochemistry on ultrathin frozen sections. Histochem J. 12:381-403.

Torossi T, Fan JY, Sauter-Etter K, Roth J, Ziak M. 2006. Endomannosidase processes oligosaccharides of alpha1-antitrypsin and its naturally occurring genetic variants in the Golgi apparatus. Cell Mol Life Sci. 63:1923-1932.

Torossi T, Roth J, Ziak M. 2007. A single tryptophan residue of endomannosidase is crucial for Golgi localization and in vivo activity. Cell Mol Life Sci. 64:1881-1889.

Towbin H, Staehelin T, Gordon J. 1979. Electrophoretic transfer of proteins from polyacrylamide gels to nitrocellulose sheets: Procedure and some applications. Proc Natl Acad Sci USA. 76:4350-4354.

Trombetta ES, Simons JF, Helenius A. 1996. Endoplasmic reticulum glucosidase II is composed of a catalytic subunit, conserved from yeast to mammals, and a tightly bound noncatalytic HDEL-containing subunit. J Biol Chem. 271:27509-27516.

Wang SY, Williams DL. 1982. Biosynthesis of the vitellogenins. Identification and characterization of nonphosphorylated precursors to avian vitellogenin I and vitellogenin II. J Biol Chem. 257:3837-3846.

Weng S, Spiro RG. 1996. Evaluation of the early processing routes of $N$-linked oligosaccharides of glycoproteins through the characterization of Man8GlcNAc2 isomers: Evidence that endomannosidase functions in vivo in the absence of a glucosidase blockade. Glycobiology. 6:861868.

West DW, Clegg RA. 1984. Casein kinase activity in rat mammary gland Golgi vesicles. Demonstration of latency and requirement for a transmembrane ATP carrier. Biochem J. 219:181-187.

Ziak M, Kerjaschki D, Farquhar MG, Roth J. 1999. Identification of megalin as the sole rat kidney sialoglycoprotein containing poly alpha2,8 deaminoneuraminic acid. J Am Soc Nephrol. 10:203-209.

Zuber C, Spiro MJ, Guhl B, Spiro RG, Roth J. 2000. Golgi apparatus immunolocalization of endomannosidase suggests post-endoplasmic reticulum glucose trimming: Implications for quality control. Mol Biol Cell. 11:42274240 . 